\title{
Silica-Calix Hybrid Composite of Allyl Calix[4]arene Covalently Linked to MCM-41 Nanoparticles for Sustained Release of Doxorubicin into Cancer Cells
}

\author{
Nilesh Narkhede, Bhawna Uttam, Ravinder Kandi, and Chebrolu Pulla Rao*(i) \\ Bioinorganic Laboratory, Department of Chemistry, Indian Institute of Technology Bombay, Powai, Mumbai 400076, India
}

Supporting Information

\begin{abstract}
An inorganic-organic hybrid material, MCMallylCalix, was synthesized by covalent modification of an MCM-41 surface with a tetra-allyl calixarene conjugate. The synthesized hybrid was characterized by ${ }^{13} \mathrm{C}$ and ${ }^{29} \mathrm{Si}$ MASNMR, Fourier transform infrared (FT-IR), BrunauerEmmett-Teller surface area, thermogravimetric analysis (TGA), and transmission electron microscopy (TEM) analyses. The application of this MCM-allylCalix hybrid has been demonstrated for loading and in vitro release of doxorubicin (Dox) in phosphate-buffered saline (PBS) buffer as well as in the cancer cells, viz., MCF7, HeLa, and MDA-

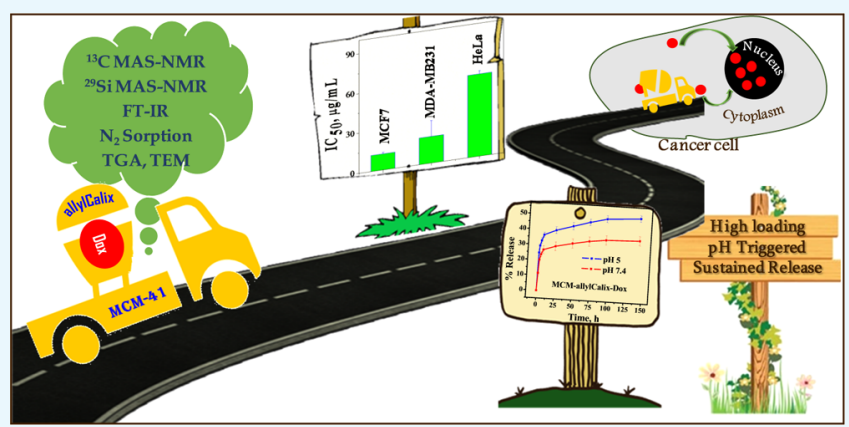
MB231. The Dox-loaded hybrid, MCM-allylCalix-Dox, was characterized by TEM, FT-IR, TGA, $\mathrm{N}_{2}$ sorption, diffuse refectance spectroscopy-UV, and fluorescence microscopy to confirm the presence of the drug. The release study of the drug from MCM-allylCalix-Dox was carried out in PBS buffer at pH 5 and 7.4. The results showed $\sim 140 \%$ increase in the release of Dox at $\mathrm{pH} 5$ compared to that at $\mathrm{pH} 7.4 \mathrm{in} 144 \mathrm{~h}$, suggesting a pH-triggered release of the drug. MCM-allylCalix-Dox releases a greater amount of Dox compared to that released from unmodified MCMDox. Cytotoxicity studies suggested that MCM-allylCalix-Dox exhibits anticancer activity that is dependent on the nature of the cell. The Dox-loaded hybrid shows more cytotoxicity for MCF7 compared to that for the HeLa and MDA-MB231 cells. This was further supported by $\sim 120 \%$ more internalization of Dox into MCF7 cells compared to that in the other two cell lines. Both fluorescence microscopy and fluorescence-activated cell sorting studies suggested concentration-dependent internalization of Dox into the MCF7 and HeLa cells. The results suggested that the inorganic-organic hybrid can be useful in sustained drug delivery into cancer cells.
\end{abstract}

\section{INTRODUCTION}

Mesoporous materials are the subject of increasing numbers of publications currently in the literature in view of their utility in different fields, such as sensing, ${ }^{1,2}$ catalysis, ${ }^{3,4}$ adsorption/ separation, ${ }^{5}$ nanomedicine, and drug delivery. ${ }^{6}$ This is because of their superior properties, such as large surface area, high pore volume, tunable pore size, and easily modifiable outer surface. ${ }^{4}$ Mesoporous silica nanoparticles (MSNs) have shown great potential as a drug delivery vehicle due to their mesoporous structure, surface functionality, biocompatibility, high drug loading capacity, and capacity to withstand external response, such as mechanical stress and so on. ${ }^{6}$ A drug delivery system will be considered versatile if it can deliver precise quantities of drug to the targeted cells or tissues in a controlled manner to enhance drug efficiency. MSNs have indeed shown such properties. ${ }^{7,8}$ Additional advantages of such materials include scaling up of the synthesis to meet commercial demands and easy clearance from the body. ${ }^{9}$ In addition, the presence of silanol groups in these materials allows them to be functionalized with different organic groups, which will in turn result in a greater affinity to bind to drugs. ${ }^{10}$ Having seen the positive outcome of such systems in drug delivery, it is worth investing efforts further on their fine-tuning. Such fine-tuning can be achieved by the covalent modification between the organic molecule and the mesoporous silica matrix. To perform such covalent modification, we have chosen macrocyclic calixarene for a number of reasons: (i) amphiphilic nature, (ii) presence of aromatic cavity, (iii) easy organic modifiability, (iv) dominance in host-guest chemistry, and ( $v$ ) as receptors for ions and molecules. ${ }^{11-13}$ Indeed, our group played a pivotal role in all of these studies. $^{14-17}$ Therefore, the combination of mesoporous silica materials in covalent conjugation with calixarenes can lead to a new class of materials, which will exhibit the advantages of both the precursors. Only a limited number of such materials were reported with different properties, such as sensing, ${ }^{18}$ adsorption of metal ions ${ }^{19-23}$ and molecules, ${ }^{24,25}$ removal of pollutants, $^{26-29}$ and catalysis. $^{30-34}$ In the literature, few calixarene conjugates were shown to act as gatekeepers in drug loading and release. ${ }^{35,36}$ It is interesting to see the applicability of mesoporous silica functionalized with an organic

Received: November 25, 2017

Accepted: December 27, 2017

Published: January 9, 2018 
Scheme 1. Synthesis of Allyl Calixarene-Functionalized Mesoporous Silica ${ }^{a}$
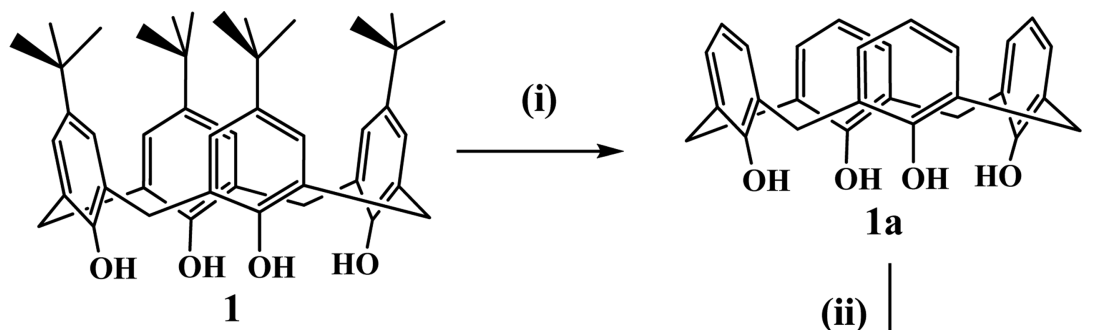

(ii)

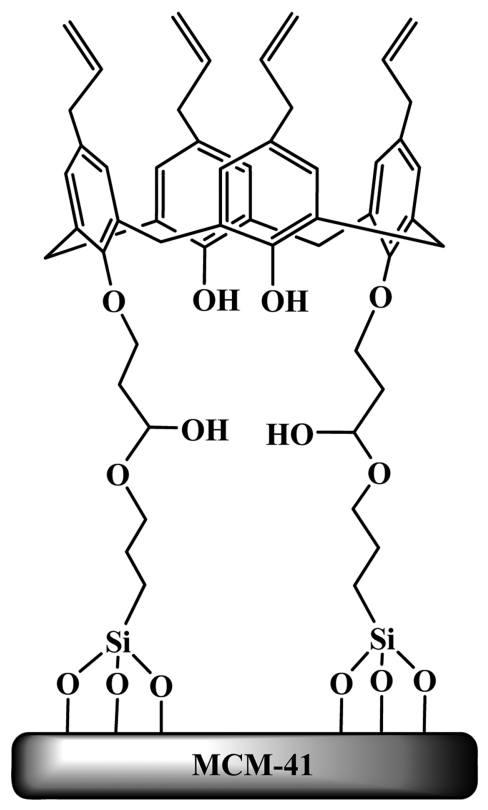

(v)

(iv)

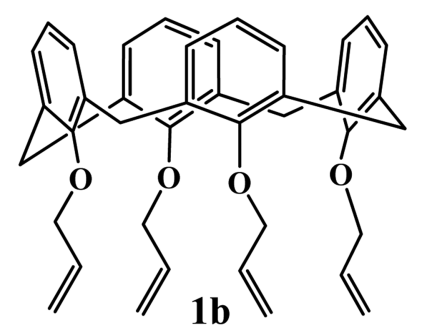

(iii)

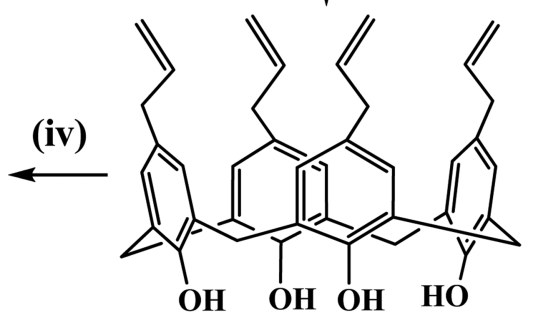

allylCalix

a(i) Anhydrous $\mathrm{AlCl}_{3}$, phenol, toluene, room temperature, $8 \mathrm{~h}$; (ii) $\mathrm{NaH} /$ tetrahydrofuran (THF), $\mathrm{CH}_{2}=\mathrm{CHCH}_{2} \mathrm{Br}, \mathrm{N}_{2}$ atmosphere, reflux, 24 h; (iii) $\mathrm{N}, \mathrm{N}$-dimethyl-aniline, $\mathrm{N}_{2}$ atmosphere, $210^{\circ} \mathrm{C}, 6 \mathrm{~h}$; (iv) GPTMS, toluene, $\mathrm{N}_{2}$ atmosphere, $80{ }^{\circ} \mathrm{C}, 15 \mathrm{~h}$; (v) MCM- $41,110{ }^{\circ} \mathrm{C}, 48 \mathrm{~h}$.
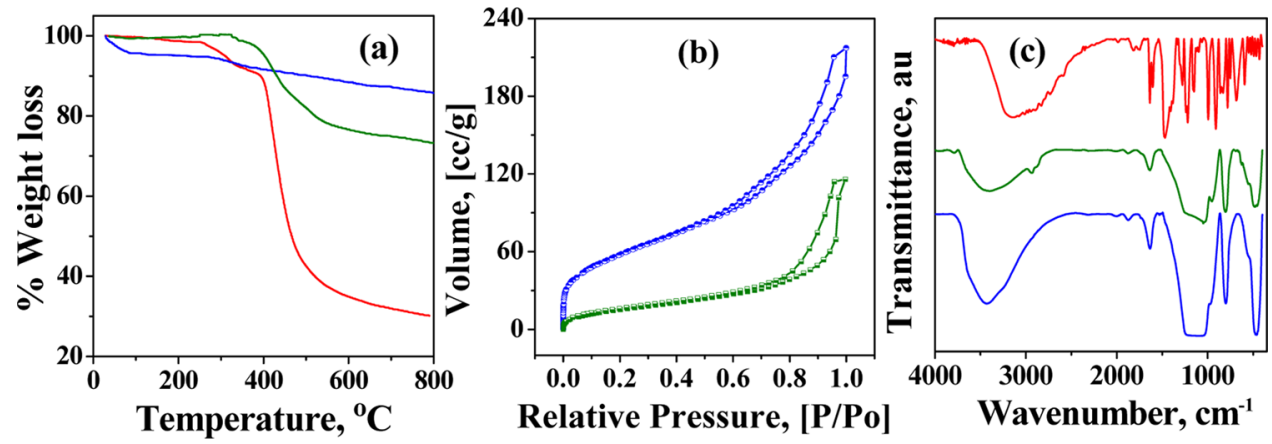

Figure 1. (a) TGA curves under a $\mathrm{N}_{2}$ atmosphere. (b) $\mathrm{N}_{2}$ sorption isotherms at $77 \mathrm{~K}$. (c) FT-IR spectra. Color code: MCM-41, blue; allylCalix, red; and MCM-allylCalix, green.

calixarene host for the loading and release of drug into cancer cells.

Therefore, this article deals with covalently functionalized MCM-41 with the tetra-allyl derivative of calix[4] arene to result in a silica-calix hybrid (MCM-allylCalix) and was characterized by spectroscopy and microscopy. The textural properties were characterized by transmission electron microscopy (TEM) and Brunauer-Emmett-Teller (BET) surface area analysis. In the present study, doxorubicin (Dox) has been chosen because of its wide utility in the treatment of different types of cancers and its red fluorescence emission, which will help track its localization in cells. The MCM-allylCalix hybrid has been further demonstrated for its storage and release of Dox in solution and its controlled release in different types of cancer cells using fluorescence microscopy and fluorescence-activated cell sorting (FACS) studies.

\section{RESULTS AND DISCUSSION}

Development of Covalently Modified Mesoporous Silica (MCM-allyICalix) and Its Precursors. The upper-rim 
tetra-allyl derivative of calix[4] arene (allylCalix) was synthesized in three steps starting from $p$-tert-butyl calix[4]arene, as given in Scheme 1, and was characterized by ${ }^{1} \mathrm{H}$ NMR, ${ }^{13} \mathrm{C}$ $\mathrm{NMR}$, and electrospray ionization mass spectrometer (ESIMS). The allyCalix was shown to be in cone conformation based on the bridge $-\mathrm{CH}_{2}$ proton signals. MCM-41 was synthesized and characterized as reported in the literature ${ }^{37}$ before making its covalent conjugate product with allylCalix to result in MCM-allylCalix in the presence of (3glycidyloxypropyl)trimethoxysilane (GPTMS). The MCMallylCalix was characterized by thermogravimetric analysis (TGA), Fourier transform infrared (FT-IR), BET surface area, ${ }^{29} \mathrm{Si}$ and ${ }^{13} \mathrm{C}$ MAS-NMR, and TEM.

In TGA (Figure 1a), MCM-41 showed an initial weight loss of $4.4 \%$ up to $100{ }^{\circ} \mathrm{C}$ because of the loss of adsorbed water. This is followed by a gradual weight loss above $290{ }^{\circ} \mathrm{C}$ because of the condensation of silanol groups to form siloxane bonds. The allyCalix showed a $68 \%$ decrease in weight up to $700{ }^{\circ} \mathrm{C}$ under a $\mathrm{N}_{2}$ atmosphere because of the combustion of calixarene. The silica-calix hybrid (MCM-allylCalix) shows an additional weight loss of $\sim 12.2 \%$ at $700{ }^{\circ} \mathrm{C}$ because of the loss of organic functionality. This resulted in the weight fraction of allylCalix in the hybrid as $\sim 18 \%$.

In the hybrid, MCM-allylCalix, MCM-41 was covalently functionalized by the calixarene derivative so as to block the pores partly. This has been supported by BET measurements (Figure $1 \mathrm{~b}$ ), which show about $64 \%$ blocking of the surface area, that is, the surface area of $628 \mathrm{~m}^{2} / \mathrm{g}$ in MCM-41 decreases to $222 \mathrm{~m}^{2} / \mathrm{g}$ in the hybrid. The pore width of MCM-41 was 6.5 $\mathrm{nm}$, which was eventually reduced to $1.5 \mathrm{~nm}$ after the incorporation of allylCalix, suggesting significant covalent functionalization of MCM-41 by allylCalix. All of the nitrogen isotherms are of type (IV) in nature. The adsorption branch of each isotherm displayed a sharp inflection, suggesting a typical capillary condensation inside the uniform pores within the relative pressure range of $0.6-1\left(P / P_{\mathrm{o}}\right)$. The observed surface area and the pore diameter of the hybrid suggest that there is sufficient amount of nanospace available for carrying out the drug delivery application even after introducing the calixarene moiety.

The FT-IR spectra of well-dried and quantitative samples, viz., MCM-41, MCM-allylCalix, and allylCalix, are shown in Figure 1c. The FT-IR spectra of MCM-41 showed bands corresponding to asymmetric, symmetric, and bending vibrations for the $\mathrm{Si}-\mathrm{O}-\mathrm{Si}$ moiety, respectively, at 10001300 (broad), 808, and $470 \mathrm{~cm}^{-1}$. The $-\mathrm{OH}$ stretching vibrations of water and $\mathrm{Si}-\mathrm{OH}$ were observed as broad absorptions centered at $3434 \mathrm{~cm}^{-1}$, whereas their bending vibrations were observed at 1635 and $965 \mathrm{~cm}^{-1}$, respectively. The FT-IR spectrum of the MCM-allylCalix hybrid also exhibited all of the bands corresponding to MCM-41. The new vibrational bands observed at 2935 and $2878 \mathrm{~cm}^{-1}$ are attributed to the asymmetric and symmetric stretching vibrations of $-\mathrm{CH}_{2}$ moieties present in the covalently modified calixarene counterpart. The broad band observed in the 3000$3700 \mathrm{~cm}^{-1}$ region is due to the $-\mathrm{OH}$ of the silanol groups of MCM-41 and those from the calixarene part. The width and area under the $-\mathrm{OH}$ stretching vibrational band of the MCMallylCalix hybrid are dramatically decreased compared to those of MCM-41 and allylCalix, suggesting the condensation of several of the $-\mathrm{OH}$ groups when the hybrid is formed. The $-\mathrm{OH}$ stretching band position is shifted from 3153 to 3405 $\mathrm{cm}^{-1}$ on going from allylCalix to the hybrid, suggesting a significant decrease in free $-\mathrm{OH}$ moieties.

The ${ }^{13} \mathrm{C}$ MAS-NMR spectra of the MCM-allylCalix (Figure 2a) showed peaks corresponding to methylene (32 and 38

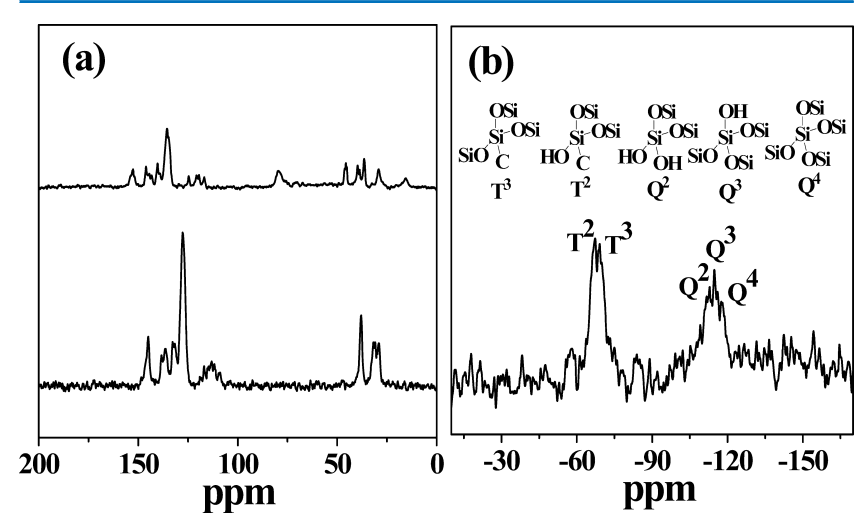

Figure 2. (a) ${ }^{13} \mathrm{C}$ MAS-NMR spectra of allylCalix (lower) and MCMallylCalix (upper). (b) ${ }^{29} \mathrm{Si}$ MAS-NMR spectra of MCM-allylCalix. The coordination cores, e.g., $\mathrm{Q}^{2}, \mathrm{Q}^{3}$, and $\mathrm{Q}^{4}$ and $\mathrm{T}^{2}$ and $\mathrm{T}^{3}$, are shown in the upper half.

ppm), allyl (110-122 ppm), and aromatic (128-153 ppm) carbons of the allylCalix derivative. These are marginally downfield shifted as compared to those of the free allylCalix derivative. The ${ }^{29} \mathrm{Si}$ MAS-NMR spectra of the MCM-allylCalix show the presence of a broad envelop in the -107 to -120 ppm region supporting the inorganic silica species, such as $\mathrm{Q}^{2}$ $(-112 \mathrm{ppm}), \mathrm{Q}^{3}(-115 \mathrm{ppm})$, and $\mathrm{Q}^{4}(-118 \mathrm{ppm})$, as given in Figure $2 \mathrm{~b}$. The two other signals appearing at -69 and -67 ppm correspond to the $\mathrm{T}^{2}$ and $\mathrm{T}^{3}$ functionalities on the silicon arising from $\left[(-\mathrm{OSi})_{2} \mathrm{Si}(\mathrm{R})(\mathrm{OH})\right]$ and $\left[(-\mathrm{OSi})_{3} \mathrm{Si}(\mathrm{R})\right]$, respectively. The peaks corresponding to the " $\mathrm{T}$ " species support the covalent modification of silica by the organic calixarene conjugate. Thus, the FT-IR, ${ }^{13} \mathrm{C}$, and ${ }^{29} \mathrm{Si}$ MASNMR data confirm the presence of an intact calixarene conjugate linked covalently to the surface silanol groups of MCM-41.

The TEM images of MCM-41 and the MCM-allylCalix hybrid are given in Figure 3. The mesoporous silica nanoparticles of MCM-41 are spherical and well-dispersed with an average size of $120-140 \mathrm{~nm}$ with two-dimensional ordering in mesoporous channels, which are characteristic of MCM-41 (Figure 3a-d). The covalent functionalization of MCM-41 by the allylCalix reduces the particle size by one-half of the unfunctionalized one but with enhanced aggregation (Figure $3 \mathrm{e}-\mathrm{h}$ ). The changes occurred in the shape and size of the MSNs are expected because of the covalent modification, and our results agree well with the literature. ${ }^{38-40}$ The size reduction could be due to either the flexible nature of the pores of MSNs or the dissolution of these during the preparation of the hybrid. It is mentioned in the literature that the MSNs with size $>100 \mathrm{~nm}$ will have limitation while crossing the biological barriers, such as, cell membrane. In the present study, the covalent modification of MCM-41 by allylCalix leads to the reduction in particle size along with alteration in the aggregation state and surface morphology, which can improve the activity of the hybrid as compared to that of simple MCM41. This is an added advantage of the covalent modification of MCM-41, while the presence of calixarene moiety brings an additional hydrophobic core, which is useful in the uptake of 

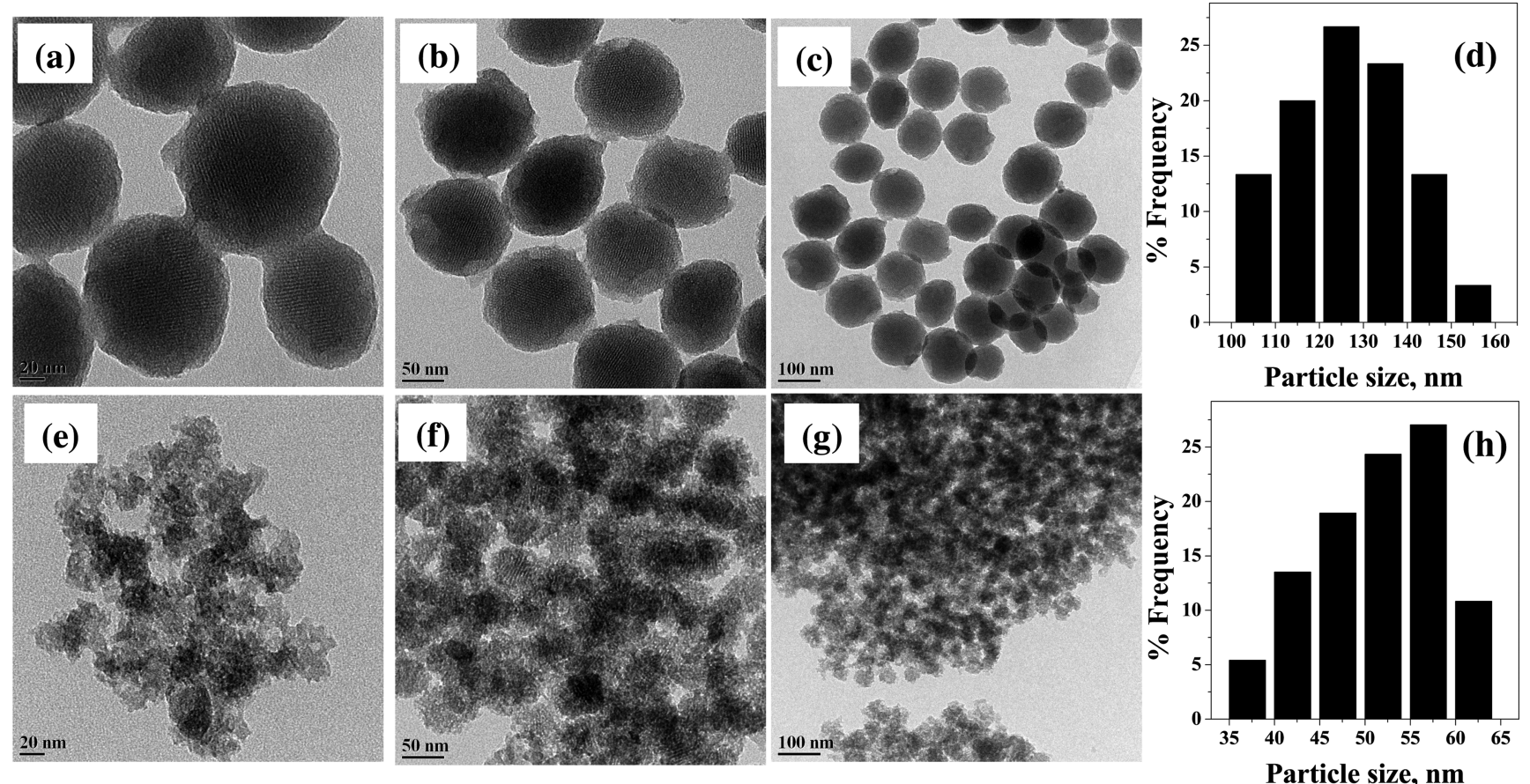

Figure 3. (a-c) TEM images of MCM-41 nanoparticles at different scales, viz., 20, 50, and $100 \mathrm{~nm}$, respectively and (d) their particle size distribution. (e-g) TEM images of MCM-allylCalix at 20, 50, and $100 \mathrm{~nm}$ scales and (h) their particle size distribution.

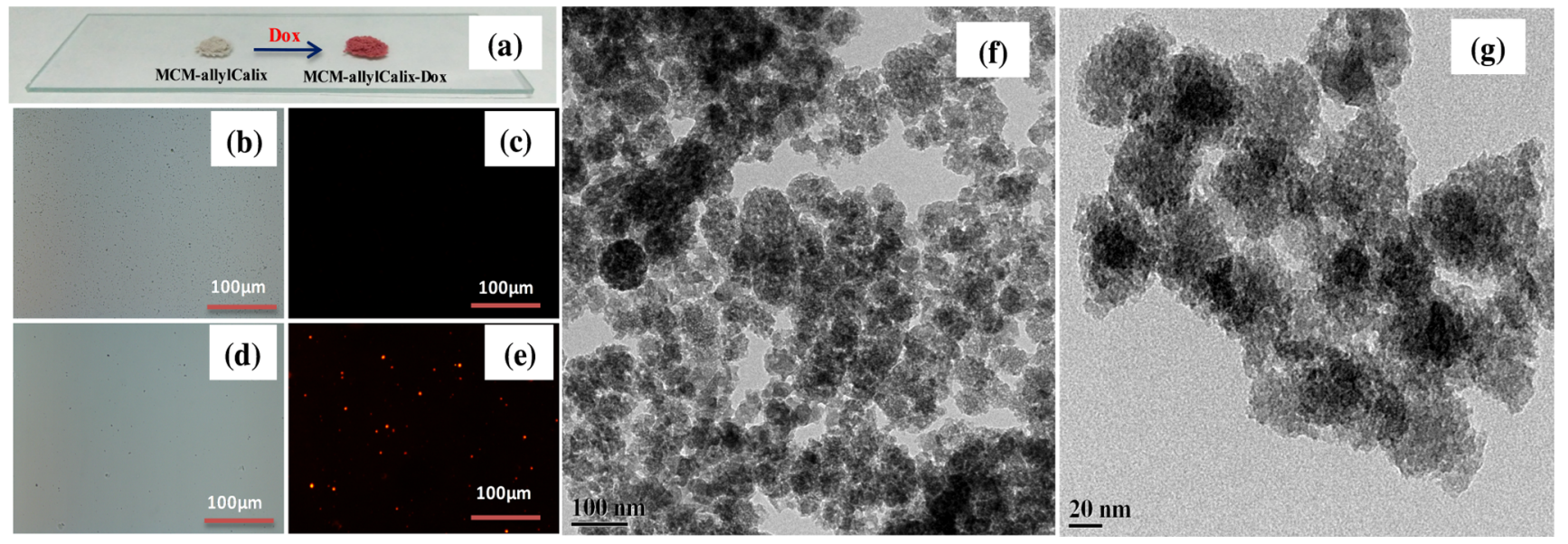

Figure 4. (a) Photographic images of MCM-allylCalix and MCM-allylCalix-Dox as powders. (b, c) Bright field and red field fluorescence microscopy images of MCM-allylCalix (Dox-free). (d) and (e) Same as (b) and (c) but for Dox-loaded MCM-allylCalix-Dox. (f, g) TEM images of MCMallylCalix-Dox at 100 and $20 \mathrm{~nm}$ scales.

the drug. Even after covalent modification, the porous surface morphology is clearly visible in TEM of the MCM-allylCalix hybrid compound.

Loading and Characterization of Dox onto the SilicaCalix Hybrid. To demonstrate the applicability of the MCMallylCalix as a vehicle for drug storage and release, the silicacalix hybrid was loaded with Dox by mixing the hybrid with the drug and incubating it for $24 \mathrm{~h}$. The amount of the loaded Dox was evaluated by measuring the absorbance of the leached out Dox into alcohol and comparing this with the standard curve. The Dox loading onto the silica-calix hybrid was $30.5 \mu \mathrm{g} / \mathrm{mg}$. As a control, Dox was loaded onto MCM-41 and resulting MCM-Dox has a loading of $10.5 \mu \mathrm{g} / \mathrm{mg}$. Thus, the drug loading of MCM-41 was increased by at least $300 \%$ upon converting it into the silica-calix hybrid by covalent linking of allylCalix. This suggests that the presence of organic functionality helps in loading a higher concentration of Dox on the carrier owing to the introduction of a more hydrophobic calixarene core.

MCM-allylCalix-Dox was characterized by TEM, FT-IR, TGA, $\mathrm{N}_{2}$ sorption, diffuse refectance spectroscopy (DRS)-UV, and fluorescence microscopy to confirm the presence of Dox. Whereas MCM-allylCalix is colorless, the hybrid exhibits a red color when loaded with Dox (Figure 4a). As Dox is expected to emit red light, the same was observed under fluorescence microscopy, confirming the successful loading of Dox in the MCM-allylCalix hybrid (Figure $4 \mathrm{~b}-\mathrm{e}$ ). The TEM of MCMallylCalix-Dox (Figure 4f,g) showed spherical particles with a porous surface morphology where Dox is well-dispersed on the entire surface. A comparison of the micrographs given in Figure $3 \mathrm{e}-\mathrm{g}$ with those given in Figure $4 \mathrm{f}, \mathrm{g}$ reveals that the incorporation of Dox into the hybrid does not appreciably change the morphology of the particles. 

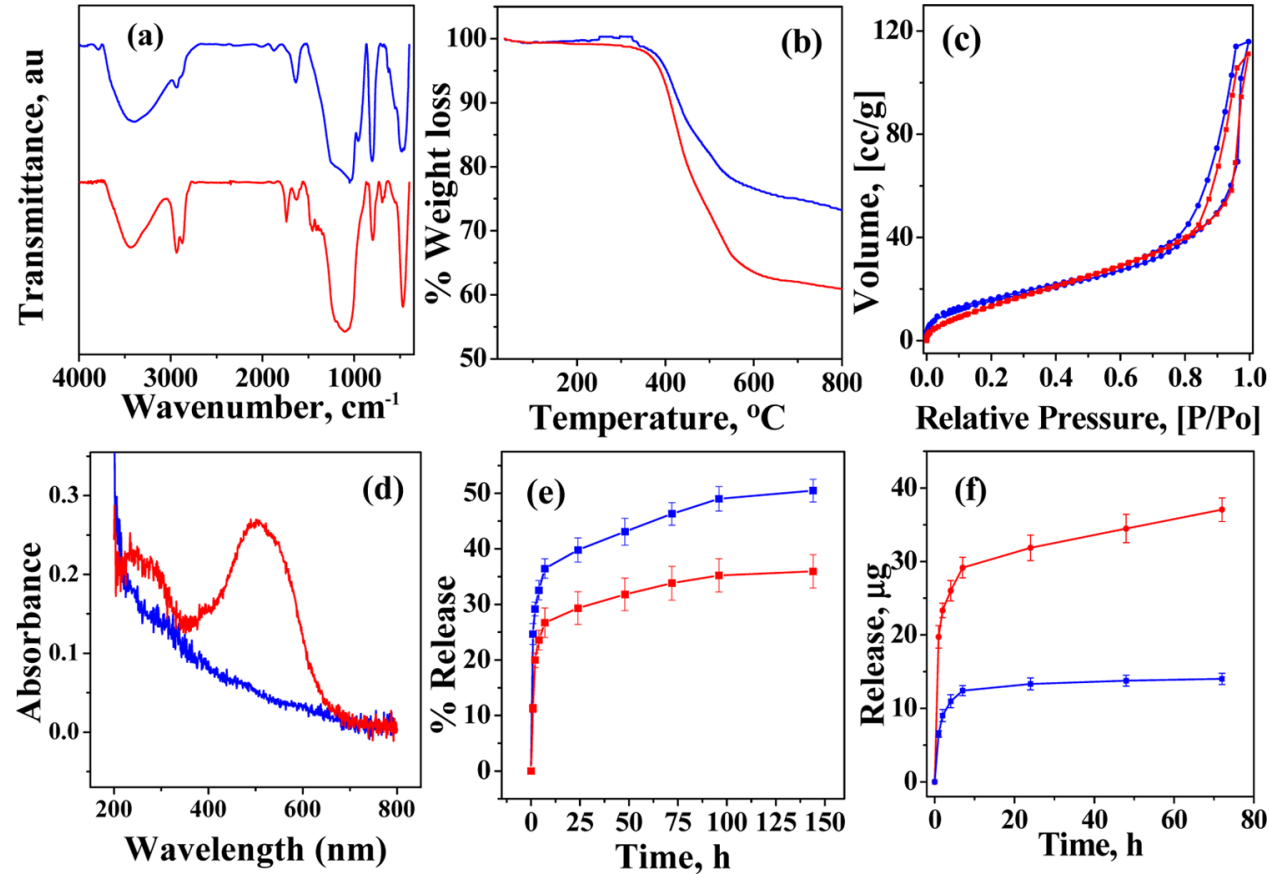

Figure 5. (a) FT-IR spectra, (b) TGA curves, (c) $\mathrm{N}_{2}$ sorption isotherms, and (d) DRS-UV spectra. The color code for (a)-(d): MCM-allylCalix (Dox-free), blue and MCM-allylCalix-Dox (Dox-loaded), red. (e) Dox release profile for MCM-allylCalix-Dox in phosphate-buffered saline (PBS) buffer at pH 7.4 (red) and pH 5 (blue). (f) Dox release profile for MCM-allylCalix-Dox (red) and MCM-Dox (blue) in PBS buffer at pH 5.

The FT-IR spectra of the Dox-loaded hybrid showed asymmetric, symmetric, and bending vibrations of $-\mathrm{CH}_{2}-$ (2936, 2872, and $1462 \mathrm{~cm}^{-1}$ ) with increased intensity, suggesting an increased organic functionality on the hybrid. In addition to this, the carbonyl group stretching vibration $\left(1736 \mathrm{~cm}^{-1}\right)$ for the Dox-loaded hybrid supports the presence of Dox by FT-IR (Figure 5a). The Dox-loaded hybrid is expected to show a greater weight loss in TGA. The presence of Dox is supported by the increase in the weight loss from 25.4 to $38.1 \%$ in the temperature range $300-700{ }^{\circ} \mathrm{C}$ on going from MCM-allylCalix to its Dox-loaded hybrid (Figure 5b). MCMallylCalix-Dox shows no significant change in $\mathrm{N}_{2}$ adsorption (Figure 5c). However, there is a significant shift in capillary condensation, which was within the relative pressure $\left(P / P_{\mathrm{o}}\right)$ range of $0.6-1$ in case of MCM-allylCalix, and this has been changed to $0.84-1\left(P / P_{\mathrm{o}}\right)$ in the Dox-loaded hybrid. The DRS-UV spectrum of MCM-allylCalix-Dox shows the characteristic band with maximum at $490 \mathrm{~nm}$, confirming the presence of Dox in the loaded hybrid (Figure 5d). The presence of Dox was also shown by fluorescence microscopy (Figure 4e).

In Vitro Release of the Drug from MCM-allylCalix-Dox. The in vitro release of the drug from MCM-allylCalix-Dox in PBS buffer at $\mathrm{pH} 7.4$ and 5 was investigated to study the release profile of Dox from the hybrid with respect to time. The cumulative release of Dox mainly occurred in the first $7 \mathrm{~h}$ under both the $\mathrm{pH}$ conditions, which reached 26.4 and 36.3\%, respectively, at $\mathrm{pH} 7.4$ and 5 (Figure 5e). This initial burst of Dox release could be attributed to the release of weakly bound Dox on the surface of the hybrid. Thereafter, very slow and sustained release of Dox was observed from 7 to $144 \mathrm{~h}$, reaching 35.9 and 50.5\% release, respectively, at $\mathrm{pH} 7.4$ and 5 . The release of Dox is at least $40 \%$ greater at $\mathrm{pH} 5$ as compared to that at $\mathrm{pH} \mathrm{7.4,} \mathrm{both} \mathrm{at} 7 \mathrm{~h}$ and even at $144 \mathrm{~h}$. Thus, under acidic conditions, Dox is released in a greater concentration.
The data shown in Figure 5e supports that the rate of release of Dox is greater at low $\mathrm{pH}$ due to the possible protonation followed by increased solubility of Dox. Thus, Dox release sustains for more than 6 days. The gradual release behavior and the prolonged release times are favorable for the tumor therapy because sustainable and continued release of drug from the carrier can effectively kill cancer cells and inhibit tumor growth in the treatment. ${ }^{41}$

It is understood from Figure $5 \mathrm{f}$ that the amount of Dox released from the MCM-allylCalix hybrid is higher $(29.1 \mu \mathrm{g}$ Dox) as compared to that from simple MCM, i.e., MCM-Dox $(12.3 \mu \mathrm{g}$ Dox $)$, up to $7 \mathrm{~h}$ of the release time at $\mathrm{pH}$ 5. Following this, very slow and sustained release of Dox was observed from the hybrid for more than $72 \mathrm{~h}$, whereas in case of inorganic MCM-Dox alone, the release of Dox $(13.2 \mu \mathrm{g})$ saturates after $24 \mathrm{~h}$, amounting to a burst of release in the latter case. Thus, all of the data supports that the silica-calix hybrid gives sustained release of drug over a period of several days as compared to that from the unmodified MCM-41 at $\mathrm{pH} 5$ in PBS.

Cytotoxicity of the Dox-Free and Dox-Loaded SilicaCalix Hybrid for Cancer Cells. To understand the biocompatibility of the MCM-allylCalix (Dox-free) hybrid, the cell viability assay was performed by the 3-(4,5dimethylthiazol-2-yl)-2,5-diphenyltetrazolium bromide (MTT) method on three different cancer cell lines, viz., MCF7, MDAMB231, and HeLa, and the corresponding data is given in Figure 6. The Dox-free hybrid shows greater cell viability for MDA-MB231 cells, whereas least cell viability for MCF7 cells at both 24 and $48 \mathrm{~h}$ of incubation. The Dox-free control showed $150 \%$ more cell viability in the case of MDA-MB231 and HeLa cells as compared to that for MCF7 cells. The Dox-loaded hybrid showed less cell viability as compared to that of the Doxfree hybrid for all of the cell lines. The Dox-loaded hybrid showed no significant change in the MCF7 cell viability at $24 \mathrm{~h}$; however, the cell viability dramatically decreased by about 

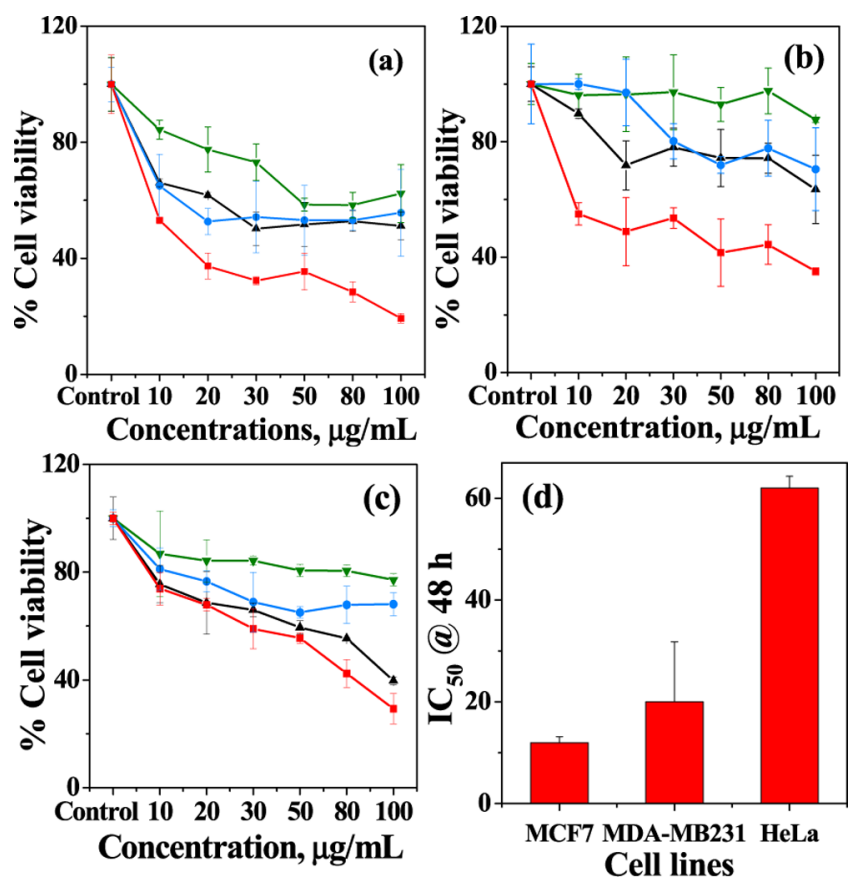

Figure 6. Cell viability of MCM-allylCalix and MCM-allylCalix-Dox on (a) MCF7, (b) MDA-MB231, and (c) HeLa cells at 24 and $48 \mathrm{~h}$ incubation. Only cells (untreated) are used as control. Color codes: MCM-allylCalix_24 h, green; MCM-allylCalix-Dox_24 h, black; MCM-allylCalix_48 h, blue; MCM-allylCalix-Dox_48 h, red. (d) $\mathrm{IC}_{50}$ values $($ in $\mu \mathrm{g} / \mathrm{mL}$ ) of MCM-allylCalix-Dox for the same three cell lines. The results are presented as average percentages of the cell viability over three replicas.

$300 \%$ at $48 \mathrm{~h}$ of treatment. For MDA-MB231 cells, the Doxloaded hybrid showed a decrease in the viability by $140 \%$ for 24 h treatment, which further decreased to $\sim 200 \%$ at $48 \mathrm{~h}$. The Dox-loaded hybrid showed the decrease in the cell viability for HeLa cells by $\sim 220 \%$ as compared to that of the Dox-free hybrid for both 24 and $48 \mathrm{~h}$ incubation. This way the Doxloaded system could kill MCF7 cells to a maximum extent as compared with the other two types of cells. This is due to the fact that the three cell lines used for the present study are from different tissue origins and hence possess different receptors on their cell membrane. This can result in difference in their cellular uptake of the drug.

The $\mathrm{IC}_{50}$ data given in Figure $6 \mathrm{~d}$ clearly support celldependent anticancer activity of the drug, viz., the Dox-loaded hybrid. The $\mathrm{IC}_{50}$ of the Dox-loaded hybrid for Hela cells is 6fold greater, whereas it is 2-fold greater for MDA-MB231, as compared to that for MCF7 cells. Thus, the results show that the Dox-loaded hybrid is highly effective in killing MCF7 cells up to $80 \%$ in $48 \mathrm{~h}$.

Internalization of Dox into MCF7 and HeLa Cells by FACS. On the basis of the cytotoxicity differences observed between MCF7 and HeLa cells, we thought to study the internalization of Dox. The FACS data showed no fluorescence shift in the case of just the cells alone and the cells treated with the Dox-free hybrid for both the cell lines. However, a clear fluorescence shift is observed when cells were treated with the Dox-loaded hybrid (Supporting Information, Figures S4 and S5). The relative fluorescence intensity obtained from FACS increases with an increase in the concentration of the Doxloaded hybrid as a result of greater internalization of Dox for both the cell lines (Figure 7a,b). The higher cytotoxicity of the
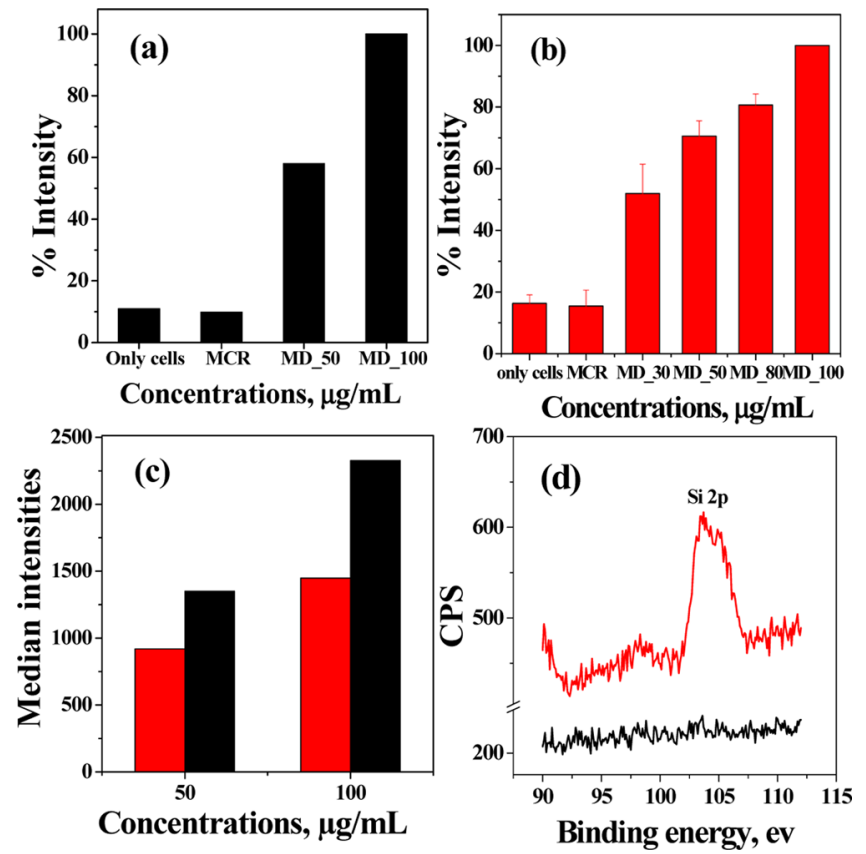

Figure 7. Fluorescence intensities for (a) MCF7 and (b) HeLa cells obtained from FACS on treating with different concentrations of the Dox-loaded hybrid. "Only cells" refers to untreated cells, and these are used as control. MCR: MCM-allylCalix and MD: MCM-allylCalixDox. In "MD_X", the "X" corresponds to the concentration in $\mu \mathrm{g} / \mathrm{mL}$. (c) Comparison of median intensities of HeLa (red) and MCF7 (black) cells. (d) XPS spectra of only HeLa cells (black) and HeLa cells treated with the silica-calix hybrid (red).

Dox-loaded hybrid for MCF7 cells as compared to that for HeLa cells was further supported by the comparison of median intensities of the two cell lines obtained from FACS (Figure $7 \mathrm{c}$ ). The MCF7 cells showed $\sim 150 \%$ more internalization of Dox as compared to that for HeLa cells for both the concentrations, which eventually resulted in greater killing of the MCF7 cells as compared to that of the other cell lines. The internalization of the silica-calix hybrid was shown by a X-ray photoelectron spectroscopy (XPS) study (Figure 7d). The HeLa cells were incubated with the Dox-free hybrid (200 $\mu \mathrm{g}$ / $\mathrm{mL}$ ) for $24 \mathrm{~h}$ and washed subsequently with water several times. The resulting cells showed the presence of Si $2 p$ in the XPS spectrum, supporting the internalization of the silica-calix hybrid in the HeLa cells. The result is confirmed because the control cells do not show Si $2 p$ in the XPS spectrum.

Localization of Dox in MCF7 and HeLa Cells by Fluorescence Microscopy. Fluorescence microscopy studies showed increasing red fluorescence with an increase in the concentration of the added Dox-loaded hybrid (Figure 8) for both the cell lines. The data further supported the localization of Dox in cytoplasm when the incubation was for $24 \mathrm{~h}$ in the case of both the cells, and further incubation led to its entry into the nucleus and decreased the cell number due to cell death (Supporting Information, Figure S6). The comparison of Dox internalization by measuring the fluorescence intensities showed $\sim 250 \%$ more internalization of the Dox-loaded hybrid into both the cells on treating with $100 \mu \mathrm{g} / \mathrm{mL}$ as compared to that with $50 \mu \mathrm{g} / \mathrm{mL}$, whereas $\sim 120 \%$ more internalization of Dox in MCF7 as compared to that in HeLa cells (Supporting Information, Figure S7). These studies suggest that the silicacalix hybrid acts as a drug carrier to cells and hence the corresponding nanoparticles are useful in cancer chemotherapy. 


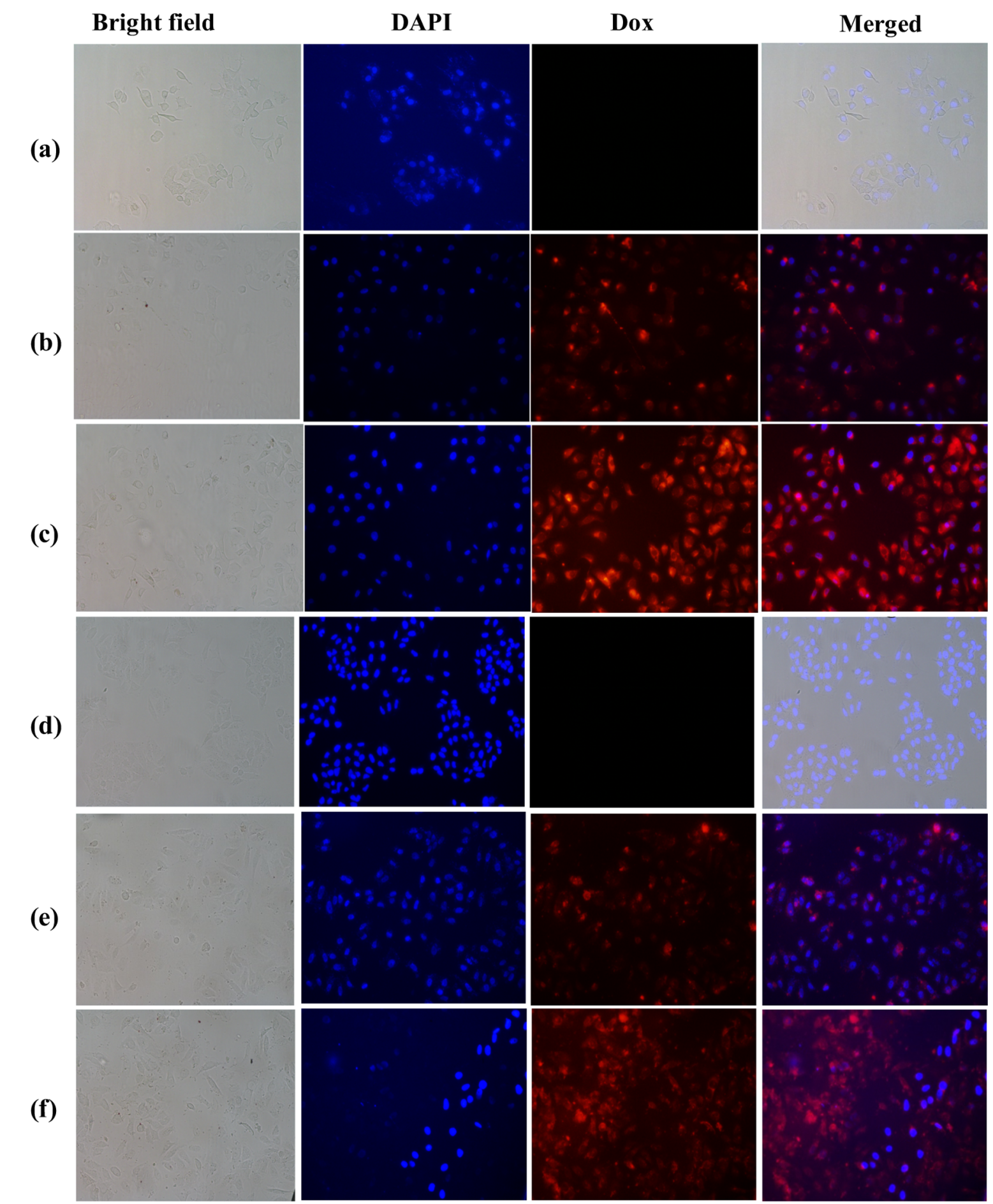

Figure 8. Localization of Dox by MCM-allylCalix-Dox using fluorescence microscopy: (a) - (c) for MCF7 and (d) - (f) for HeLa cells. (a, d) Corresponding cells alone as controls. (b, e) Cells treated with $50 \mu \mathrm{g} / \mathrm{mL}$ MCM-allylCalix-Dox. (c, f) Cells treated with $100 \mu \mathrm{g} / \mathrm{mL} \mathrm{MCM}$ allylCalix-Dox. Red fluorescence indicates Dox, and blue indicates 4',6-diamidino-2-phenylindole (DAPI) stain. The columns from left to right correspond to bright field, DAPI, Dox, and merged.

\section{CONCLUSIONS AND CORRELATIONS}

In the present article, we have successfully functionalized the surface of mesoporous silica nanoparticles covalently by allylCalix through its lower rim, which leads to the inorganic-organic hybrid, MCM-allylCalix. The presence of the organic functionalization was confirmed by various spectroscopy techniques and was quantified by thermal analysis, which suggested the presence of $\sim 18 \%$ of the organic calixarene moiety in the hybrid compound. Furthermore, the changes observed in the FT-IR spectra and $\mathrm{N}_{2}$ sorption isotherm supported the formation of the MCM-allylCalix hybrid. ${ }^{13} \mathrm{C}$ MAS-NMR spectra of the hybrid showed the presence of all of the typical carbons of the allylCalix derivative. ${ }^{29} \mathrm{Si}$ MAS-NMR spectra of the hybrid showed the presence of the $\mathrm{T}^{2}$ and $\mathrm{T}^{3}$ silicon species, suggesting the presence of covalently attached organic functionality onto the MCM-allylCalix hybrid. All of 
Scheme 2. Schematic Representation of the Highlights of the Synthesis, Characterization, Drug Delivery, and Anticancer Activity of MCM-allylCalix

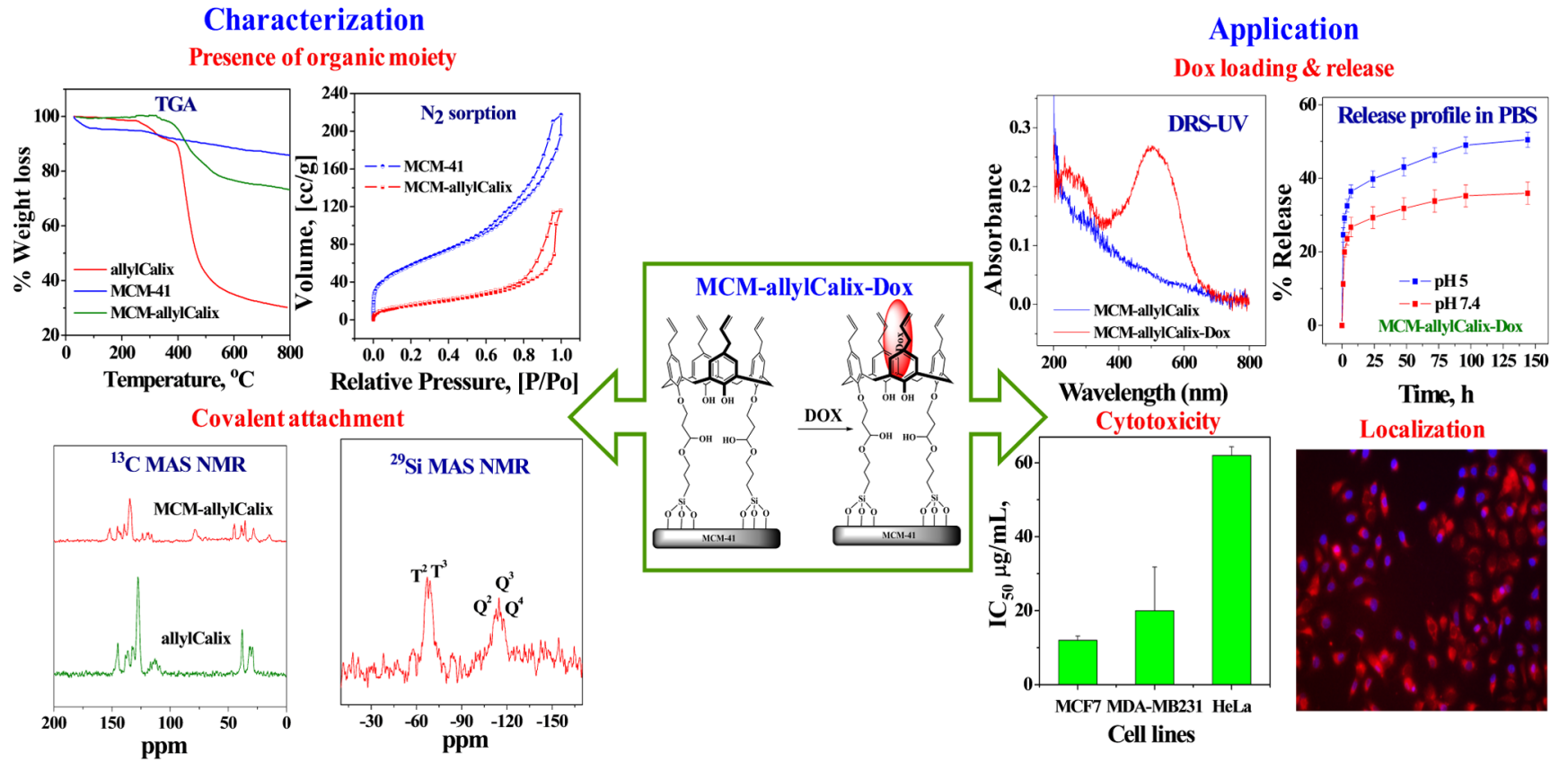

the experimental data is consistent with the presence of the covalently integrated calixarene moiety onto the inorganic silica matrix. Furthermore, the TEM studies revealed that after the covalent modification there is a significant reduction in the size of the silica nanoparticles with a high degree of aggregation. Indeed, such aggregation is an expected phenomenon of the conjugates of calixarenes. ${ }^{15,16}$

The MCM-allylCalix hybrid has shown a great potential for acting as a carrier of anticancer drug Dox. The studies revealed that the Dox loading by the hybrid was increased up to $300 \%$ as compared to that by unfunctionalized MCM-41. This is due to the presence of the calixarene cavity as well as the allyl moiety providing a suitable hydrophobic environment for the drug to be loaded. The Dox-loaded hybrid, MCM-allylCalix-Dox, was characterized by TEM, FT-IR, TGA, DRS-UV, and $\mathrm{N}_{2}$ sorption studies, which supported the successful loading of Dox on the hybrid, and was confirmed by its red fluorescence emission, which is the characteristic of Dox. The in vitro release into PBS buffer showed a higher release rate of Dox in an acidic medium at $\mathrm{pH} 5$ as compared to that in the neutral medium at $\mathrm{pH}$ 7.4. Overall, the Dox release was observed to be 35.9 and $50.5 \%$, respectively, at $\mathrm{pH} 7.4$ and 5 in $144 \mathrm{~h}$. On comparing the release profiles, it was observed that MCM-allylCalix-Dox (29.1 $\mu$ g Dox) releases $240 \%$ greater amount of the drug as compared to that from the control, MCM-Dox (12.3 $\mu \mathrm{g}$ Dox). The hybrid system exhibited slow and sustained release of Dox for few days, whereas saturation occurs within 1 day in the case of simple MCM-41. The presence of the aromatic hydrophobic core as well as the steric effects of the bulkier organic calixarenes plays a vital role in the slow and sustained release of Dox from the MCM-allylCalix hybrid. All of these features can be well-correlated from Scheme 2.

The cytotoxicity studies showed that among the three different types of cancer cells, the Dox-loaded hybrid is more toxic to MCF7 cells as than to the HeLa and MDA-MB231 cells. The results were further supported by cell internalization of MCM-allylCalix-Dox by FACS and fluorescence microscopy.
Both FACS and microscopy data suggested concentrationdependent internalization of the Dox-loaded hybrid into the MCF7 and HeLa cells. Both the studies showed $150 \%$ greater internalization of the Dox-Loaded hybrid in MCF7 cells as compared to that in HeLa cells. The fluorescence microscopy studies showed the localization of Dox in the cytoplasm in $24 \mathrm{~h}$ and in nucleus with an increasing incubation time. The entry of the MCM-allylCalix hybrid (Dox-free) into the HeLa cells was further confirmed by XPS analysis. All of these studies support that the silica-calix hybrid acts as a drug vehicle and provides controlled release of drug into the cancer cells and is of great use in cancer chemotherapy.

\section{EXPERIMENTAL SECTION}

All of the chemicals used were of A.R. grade. Tetraethylorthosilicate and (3-glycidyloxypropyl)trimethoxysilane (GPTMS) were purchased from Sigma-Aldrich. All other solvents and reagents used were purchased from Merck. Milli- $Q$ water is used in the present study. The upper-rim allylCalix was synthesized in three steps starting from p-tert-butyl calix[4]arene, as given in Scheme 1, and the synthesis and characterization of these are given here.

Synthesis and Characterization of 1a. Upper rim dealkylation of tert-butyl calix[4]arene was carried out as reported earlier ${ }^{42}$ in $85 \%$ yield. The product, 1a, was recrystallized by trituration from the $\mathrm{CHCl}_{3}-\mathrm{CH}_{3} \mathrm{OH}$ mixture. ${ }^{1} \mathrm{H}$ NMR: (400 MHz, $\mathrm{CDCl}_{3}$ ) $\delta: 10.19$ (s, 4H, $\left.\mathrm{ArOH}\right), 7.05$ (d, $8 \mathrm{H}, \mathrm{Ar}-\mathrm{H}$ ), 6.72 (t, 4H, Ar-H), 4.25 (d, 4H, Ar- $\left.\mathrm{CH}_{2}-\mathrm{Ar}\right), 3.54$ (d, $\left.4 \mathrm{H}, \mathrm{Ar}-\mathrm{CH}_{2}-\mathrm{Ar}\right) .{ }^{13} \mathrm{C} \mathrm{NMR}\left(\mathrm{CDCl}_{3}, 400 \mathrm{MHz}, \delta \mathrm{ppm}\right)$ : 31.72 ( $\mathrm{Ar}-\mathrm{CH}_{2}-\mathrm{Ar}$ ), 122.27, 128.26, 129.00, 148.79 (Ar-C). ESI-MS: $m / z=463.13[\mathrm{M}+\mathrm{K}]$. All of the spectra are given in Figure S1.

Synthesis and Chracterization of Lower-Rim Allyl Calix[4]arene, 1b. The lower-rim allyl calixarene conjugate was synthesized by the reported method. ${ }^{43}$ The dealkylated calixarene, 1a, (1.07 g, $2.5 \mathrm{mmol}$ ) was taken (in $50 \mathrm{~mL}$ of THF $+5 \mathrm{~mL}$ of dimethylformamide), $\mathrm{NaH}(1.0 \mathrm{~g}, 41 \mathrm{mmol})$ and 
allyl bromide ( $14 \mathrm{~g}, 115 \mathrm{mmol}$ ) were then added to this, and the reaction mixture was refluxed for $24 \mathrm{~h}$. The solvent was then removed by rotavac, and the residue was partitioned between water and $\mathrm{CHCl}_{3}$. The $\mathrm{CHCl}_{3}$ extract was washed with water and dried. The residue was recrystallized from ethanol to result in pure 1 b. Yield: $71 \%$, ESI-MS: $m / z=623.27[\mathrm{M}+\mathrm{K}]$. Elemental analysis, calculated: $\mathrm{C}=82.16 \%, \mathrm{H}=6.89 \%, \mathrm{O}=$ 10.94\% and experimental: $\mathrm{C}=78.97 \%, \mathrm{H}=6.03 \%, \mathrm{O}=$ $14.99 \%$. All of the spectra are given in Figure S2.

Synthesis and Chracterization of allylCalix. A solution of $\mathbf{1 b}(3.15 \mathrm{~g}, 5.4 \mathrm{mmol})$ in $25 \mathrm{~mL}$ of $\mathrm{N}, \mathrm{N}$-dimethylaniline was refluxed at $210{ }^{\circ} \mathrm{C}$ for $6 \mathrm{~h}$ under a $\mathrm{N}_{2}$ atmosphere. Upon acidification of the reaction mixture with concentrated $\mathrm{HCl}$, a precipitate was obtained, and the filtered crude compound (allylCalix) was recrystallized from ethanol. Yield: 91\%, ${ }^{1} \mathrm{H}$ NMR: (400 MHz, $\mathrm{CDCl}_{3}$ ) $\delta: 10.15$ (s, 4H), $6.84(\mathrm{~s}, 8 \mathrm{H}), 5.89$ (ddt, $J=17,10.5,6.8 \mathrm{~Hz}, 4 \mathrm{H}), 5.04$ (br. d, $J=17.0 \mathrm{~Hz}, 4 \mathrm{H}$ ), 5.03 (br. d, $J=17.0 \mathrm{~Hz}, 4 \mathrm{H}$ ), 4.19 (br. d, $J=9.0 \mathrm{~Hz}, 4 \mathrm{H}$ ), 3.45 (br. d, $J=9.0 \mathrm{~Hz}, 4 \mathrm{H}), 3.18(\mathrm{~d}, J=6.8 \mathrm{~Hz}, 8 \mathrm{H}) .{ }^{13} \mathrm{C} \mathrm{NMR}$ $\left(\mathrm{CDCl}_{3}, 400 \mathrm{MHz}, \delta \mathrm{ppm}\right): 31.81\left(\mathrm{Ar}-\mathrm{CH}_{2}-\mathrm{Ar}\right), 39.34(\mathrm{Ar}-$ $\left.\mathrm{CH}_{2}\right), 115.59,128.20\left(-\mathrm{CH}=\mathrm{CH}_{2}\right)$ 128.98, 133.47, 137.61, 147.07 (Ar-C). ESI-MS: $623.25[\mathrm{M}+\mathrm{K}]$. Elemental analysis, calculated: $\mathrm{C}=82.16 \%, \mathrm{H}=6.89 \%, \mathrm{O}=10.94 \%$ and experimental: $\mathrm{C}=79.36 \%, \mathrm{H}=6.75 \%, \mathrm{O}=13.87 \%$. All of the spectra are given in Figure S3.

Synthesis of Mesoporous Silica Nanoparticles, MCM41. MCM-41 was prepared as per the reported procedure. ${ }^{37}$ The product was dried in an oven and calcined in air at $550{ }^{\circ} \mathrm{C}$ for $5 \mathrm{~h}$. These particles were characterized by TEM, BET, and FT-IR.

Covalent Modification of MCM-41 with the Allyl Calixarene Conjugate (MCM-allylCalix). The synthesis of the silica-calix hybrid, MCM-allylCalix, was carried out by taking $90 \mathrm{mg}(0.15 \mathrm{mmol})$ of allylCalix with GPTMS $(72 \mu \mathrm{L}$, $0.33 \mathrm{mmol}$ ) in the presence of three drops of perchloric acid in $15 \mathrm{~mL}$ of dry toluene. The reaction mixture was heated at 80 ${ }^{\circ} \mathrm{C}$ for $15 \mathrm{~h}$ under a $\mathrm{N}_{2}$ atmosphere. This was followed by addition of MCM-41 (450 mg), and the reaction mixture was further refluxed at $110{ }^{\circ} \mathrm{C}$ for $48 \mathrm{~h}$. MCM-allylCalix was isolated by centrifugation, and the product was washed with each of the following solvents: toluene, dichloromethane, water, methanol, and acetone, and the product was then dried under vacuum for $2 \mathrm{~h}$ (yield, $378 \mathrm{mg}$ ). This was characterized by different spectral and microscopy techniques. Energy-dispersive spectrometry elemental analysis: $\mathrm{C}=25.9 \%, \mathrm{O}=53.1 \%, \mathrm{Si}=$ $21 \%$.

Drug Loading and Release. The loading of doxorubicin hydrochloride (Dox) onto the MCM-allylCalix hybrid was carried out by taking $500 \mu \mathrm{L}$ of Dox solution $(2 \mathrm{mg} / \mathrm{mL})$ along with $50 \mathrm{mg}$ of MCM-allylCalix and $500 \mu \mathrm{L}$ of water, and the reaction mixture was shaken for $24 \mathrm{~h}$ at room temperature. Then, the Dox-loaded hybrid, viz., MCM-allylCalix-Dox, was isolated by centrifugation, washed with water, and then dried under vacuum. MCM-allylCalix-Dox was taken with ethanol (1 $\mathrm{mg} / \mathrm{mL}$ ), sonicated for $2 \mathrm{~h}$, and analyzed for the leached Dox by UV-vis spectroscopy. The absorption at $490 \mathrm{~nm}$ was compared with the standard curve to estimate the concentration of loaded Dox.

The release of Dox was carried out by taking $3 \mathrm{mg}$ of the Dox-loaded hybrid in $1.5 \mathrm{~mL}$ of $165.7 \mathrm{mM}$ PBS buffer (137 $\mathrm{mM} \mathrm{NaCl}, 2.7 \mathrm{mM} \mathrm{KCl}, 8 \mathrm{mM} \mathrm{Na} \mathrm{HPO}_{4}$, and $2 \mathrm{mM}$ $\mathrm{KH}_{2} \mathrm{PO}_{4}$ ) followed by incubation with stirring up to $144 \mathrm{~h}$ at $\mathrm{pH} 7.4$ and 5. In certain time intervals, $1 \mathrm{~mL}$ of the supernatant solution was analyzed for absorption at $490 \mathrm{~nm}$ and replaced by $1 \mathrm{~mL}$ of fresh buffer solution. The amount of Dox released was measured by comparing the absorbance values with the standard curve.

Instrumental Techniques. The organic compounds were characterized by ${ }^{1} \mathrm{H}$ and ${ }^{13} \mathrm{C}$ NMR spectra recorded on Avance III-400 Bruker and ESI-MS on a Q-TOF instrument using positive ion mode. TGA analysis of the samples was carried out using Mettler Toledo Star SW 7.01 under a nitrogen atmosphere. The FT-IR spectra of quantitative samples were measured in $\mathrm{KBr}$ at $4000-400 \mathrm{~cm}^{-1}$ using a Perkin-Elmer spectrometer. The specific surface area measurements were performed on a Quantachrome Autosorb Automated Gas Sorption Instrument (Autosorb 1) with $\mathrm{N}_{2}$ adsorption at $77 \mathrm{~K}$. The TEM micrographs were measured on PHILIPS TEM model-CM 200 working at an accelerating voltage of $200 \mathrm{kV}$.

Cell Viability Assay. All of the three cancer cell lines, viz., HeLa, MCF7, and MDA-MB231, were obtained from NCCS Pune, India, and cultured in Dulbecco's modified Eagle's medium (GIBCO) supplemented with $10 \%$ fetal bovine serum (GIBCO) and $1 \%$ antibiotics (penicillin and streptomycin, GIBCO). To understand the effect of MCM-allylCalix-Dox on the viability of these three cancer cells, the 3-(4,5-dimethylthiazol-2-yl)-2,5-diphenyltetrazolium bromide (MTT) assay were performed. The cells were cultured in 96-well plates with 15 000 cells per well and were incubated for $24 \mathrm{~h}$ to get confluence of cells. The cells were then treated with different concentrations of MCM-allylCalix (as control) and MCMallylCalix-Dox $(10,20,30,50,80$, and $100 \mu \mathrm{g} / \mathrm{mL})$ separately and were incubated for 24 and $48 \mathrm{~h}$ at $37{ }^{\circ} \mathrm{C}$ under a $5 \% \mathrm{CO}_{2}$ atmosphere. After this treatment, $10 \mu \mathrm{L}$ of the MTT reagent ( 5 $\mathrm{mg} / \mathrm{mL}$ ) was added to each well by replacing the old media and incubating further for $4 \mathrm{~h}$ in the dark. The medium was then removed, and $200 \mu \mathrm{L}$ of dimethyl sulfoxide was added to dissolve the formazan crystals. The absorbance at $570 \mathrm{~nm}$ was measured using a plate reader. The cells without any nanoparticle treatment were used as a control.

Flow Cytometry. HeLa cells were cultured in 6-well plates with seed density of $0.5 \times 10^{6}$ cells and kept for $24 \mathrm{~h}$ incubation. At the confluence state, the cells were treated with MCM-allylCalix-Dox with different concentrations (30, 50, 80, and $100 \mu \mathrm{g} / \mathrm{mL}$ ) for $24 \mathrm{~h}$. For this, simple (untreated) cells and MCM-allylCalix-treated cells were used as controls. The cells were harvested from the plate by centrifugation at $1000 \mathrm{rpm}$ per $3 \mathrm{~min}$ and washed with PBS buffer twice. Then, $500 \mu \mathrm{L}$ of PBS was added to all of the samples, and the samples were analyzed by BD FACSARIA (BD Bioscience) using a red filter. These results were further analyzed using "flowing software". Similar studies were carried out even with MCF7 cell lines but by using 50 and $100 \mu \mathrm{g} / \mathrm{mL}$ concentrations of the Dox-loaded hybrid (MCM-allylCalix-Dox).

Fluorescence Microscopy. The cells were incubated in 6well plates with cover slips, and $0.5 \times 10^{6}$ cells were seeded and kept to get confluence. These were treated with MCMallylCalix-Dox of two different concentrations (50 and $100 \mu \mathrm{g}$ / $\mathrm{mL}$ ). Then, the media was removed, the cells were washed with PBS three times, a cover slip was placed on a glass slide with 4',6-diamidino-2-phenylindole (DAPI), and observed under a fluorescence microscope using red and blue filters. 


\section{ASSOCIATED CONTENT}

\section{S Supporting Information}

The Supporting Information is available free of charge on the ACS Publications website at DOI: 10.1021/acsomega.7b01852.

Spectral data of $\mathbf{1 a}, \mathbf{1 b}$, and allylCalix; raw data for flow cytometry; fluorescence microscopy images; and fluorescence intensities (PDF)

\section{AUTHOR INFORMATION}

\section{Corresponding Author}

*E-mail: cprao@iitb.ac.in.

\section{ORCID $\odot$}

Chebrolu Pulla Rao: 0000-0002-1004-0028

\section{Notes}

The authors declare no competing financial interest.

\section{ACKNOWLEDGMENTS}

CPR acknowledges financial support from the DST/SERB (EMR/2014/000985) and from J. C. Bose National Fellowship (SB/S2/JCB-066/2015) and IIT Bombay for Institute Chair Professorship. N.K.N. acknowledges SERB for National PostDoctoral Fellowship (PDF/2016/000211), B.U. acknowledges CSIR for the award of Senior Research Fellowship (09/ 087(0835)/2015-EMR-I), and R.K. thanks IIT Bombay for the award of Institute PDF.

\section{REFERENCES}

(1) Wagner, T.; Haffer, S.; Weinberger, C.; Klaus, D.; Tiemann, M. Mesoporous materials as gas sensors. Chem. Soc. Rev. 2013, 42, 40364053.

(2) Sancenón, F.; Pascual, L.; Oroval, M.; Aznar, E.; Martinez-Manez, R. Gated Silica Mesoporous Materials in Sensing Applications. ChemistryOpen 2015, 4, 418-437.

(3) Linares, N.; Silvestre-Albero, A. M.; Serrano, E.; Silvestre-Albero, J.; García-Martínez, J. Mesoporous materials for clean energy technologies. Chem. Soc. Rev. 2014, 43, 7681-7717.

(4) Corma, A. From Microporous to Mesoporous Molecular Sieve Materials and Their Use in Catalysis. Chem. Rev. 1997, 97, 23732420.

(5) Cashin, V. B.; Eldridge, D. S.; Yu, A.; Zhao, D. Surface functionalization and manipulation of mesoporous silica adsorbents for improved removal of pollutants: a review. Environ. Sci.: Water Res. Technol. 2018, 10.1039/C7EW00322F.

(6) Bharti, C.; Nagaich, U.; Pal, A. K.; Gulati, N. Mesoporous silica nanoparticles in target drug delivery system: A review. Int. J. Pharm. Invest. 2015, 5, 124-133.

(7) Song, Y.; Li, Y.; Xu, Q.; Liu, Z. Mesoporous silica nanoparticles for stimuli-responsive controlled drug delivery: advances, challenges, and outlook. Int. J. Nanomed. 2017, 12, 87-110.

(8) Aznar, E.; Oroval, M.; Pascual, L.; Murguía, J. R.; MartínezMáñez, R; Sancenón, F. Gated Materials for On-Command Release of Guest Molecules. Chem. Rev. 2016, 116, 561-718.

(9) De Jong, W. H.; Borm, P. J. A. Drug Delivery and Nanoparticles: Applications and Hazards. Int. J. Nanomed. 2008, 3, 133-149.

(10) Yuan, L.; Tang, Q.; Yang, D.; Zhang, J. Z.; Zhang, F.; Hu, J. Preparation of $\mathrm{pH}$-Responsive Mesoporous Silica Nanoparticles and Their Application in Controlled Drug Delivery. J. Phys. Chem. C 2011, 115, 9926-9932.

(11) Kim, H. J.; Lee, M. H.; Mutihac, L.; Vicens, J.; Kim, J. S. HostGuest Sensing by Calixarenes on the Surfaces. Chem. Soc. Rev. 2012, 41, 1173-1190.

(12) Kumar, R.; Lee, Y. O.; Bhalla, V.; Kumar, M.; Kim, J. S. Recent Developments of Thiacalixarene Based Molecular Motifs. Chem. Soc. Rev. 2014, 43, 4824-4870.
(13) Song, M.; Sun, Z.; Han, C.; Tian, D.; Li, H.; Kim, J. S. Calixarene-Based Chemosensors by Means of Click Chemistry. Chem. - Asian J. 2014, 9, 2344-2357.

(14) Samanta, K.; Ranade, D. S.; Upadhyay, A.; Kulkarni, P. P.; Rao, C. P. A Bimodal, Cationic, and Water-Soluble Calix[4]arene Conjugate: Design, Synthesis, Characterization, and Transfection of Red Fluorescent Protein Encoded Plasmid in Cancer Cells. ACS Appl. Mater. Interfaces 2017, 9, 5109-5117.

(15) Nehra, A.; Yarramala, D. S.; Rao, C. P. A 1,3-Capped Calix[4] Conjugate Possessing an Amine Moiety as an Anion Receptor: Reversible Anion Sensing Detected by Spectroscopy and Characterization of the Supramolecular Features by Microscopy. Chem. - Eur. J. 2016, 22, 8980-8989.

(16) Bandela, A. K.; Patrudu, S.; Rao, C. P. A fluorescent 1,3-diaminonaphthalimide conjugate of calix[4]arene for sensitive and selective detection of trinitrophenol: Spectroscopy, microscopy and computational studies, and the applicability using cellulose strips. Chem. - Eur. J. 2015, 21, 13364-13374.

(17) Joseph, R.; Rao, C. P. Ion and Molecular Recognition by Lower Rim 1,3-Di-conjugates of Calix[4]arene as Receptors. Chem. Rev. 2011, $111,4658-4702$.

(18) Lupo, F.; Capici, C.; Gattuso, G.; Notti, A.; Parisi, M. F.; Pappalardo, A.; Pappalardo, S.; Gulino, A. Optical Recognition of nButylammonium and 1,5-Pentanediammonium Picrates by a Calix[5]arene Monolayer Covalently Assembled on Silica Substrates. Chem. Mater. 2010, 22, 2829-2834.

(19) Qureshi, I.; Memona, S.; Yilmaz, M. Estimation of chromium(VI) sorption efficiency of novel regenerable p-tert-butylcalix[8]areneoctamide impregnated Amberlite resin. J. Hazard. Mater. 2009, $164,675-682$.

(20) Zhang, D.; Wang, J.; Lawson, T. R.; Bartsch, R. A. Synthesis and Lead(II) Sorption of Silica Gel-Immobilized, Di-ionizable Calix[4]arenes. Tetrahedron 2007, 63, 5076-5082.

(21) Tabakci, M.; Yilmaz, M. Sorption characteristics of $\mathrm{Cu}$ (II) ions onto silica gel-immobilized calix[4]arene polymer in aqueous solutions: Batch and column studies. J. Hazard. Mater. 2008, 151, $331-338$.

(22) Wang, J.; Zhang, D.; Lawson, T. R.; Bartsch, R. A. Sorption of heavy metal ions by silica gel-immobilized, proton-ionizable calix[4]arenes. Talanta 2009, 78, 477-483.

(23) Sayin, S.; Yilmaz, M. Synthesis of A New Calixarene Derivative and Its Immobilization Onto Magnetic Nanoparticle Surfaces for Excellent Extractants Toward Cr(VI), As(V), and U(VI). J. Chem. Eng. Data 2011, 56, 2020-2029.

(24) Thompson, A. B.; Cope, S. J.; Swift, T. D.; Notestein, J. M. Adsorption of n-Butanol from Dilute Aqueous Solution with Grafted Calixarenes. Langmuir 2011, 27, 11990-11998.

(25) Thompson, A. B.; Scholes, R. C.; Notestein, J. M. Recovery of Dilute Aqueous Acetone, Butanol, and Ethanol with Immobilized Calixarene Cavities. ACS Appl. Mater. Interfaces 2014, 6, 289-297.

(26) Chen, M.; Chen, Y.; Diao, G. Adsorption Kinetics and Thermodynamics of Methylene Blue onto p-tert-Butyl-calix[4,6,8] arene-Bonded Silica Gel. J. Chem. Eng. Data 2010, 55, 5109-5116.

(27) Zhou, T.; Song, N.; Yu, H.; Yang, Y.-W. Pillar[5,6]areneFunctionalized Silicon Dioxide: Synthesis, Characterization, and Adsorption of Herbicide. Langmuir 2015, 31, 1454-1461.

(28) Li, H.; Qu, F. Synthesis of CdTe Quantum Dots in Sol-GelDerived Composite Silica Spheres Coated with Calix[4]arene as Luminescent Probes for Pesticides. Chem. Mater. 2007, 19, 41484154.

(29) Tor, A.; Aydina, M. E.; Aydina, S.; Tabakcib, M.; Beduk, F. Removal of lindane from an aqueous solution by using aminopropyl silica gel-immobilized calix[6]arene. J. Hazard. Mater. 2013, 262, 656663.

(30) de Silva, N.; Hwang, S.-J.; Durkin, K. A.; Katz, A. Vanadocalixarenes on Silica: Requirements for Permanent Anchoring and Electronic Communication. Chem. Mater. 2009, 21, 1852-1860. 
(31) Morlanés, N.; Notestein, J. M. Grafted Ta-calixarenes: Tunable, selective catalysts for direct olefin epoxidation with aqueous hydrogen peroxide. J. Catal. 2010, 275, 191-201.

(32) Guo, Y.; Solovyov, A.; Grosso-Giordano, N. A.; Hwang, S.-J; Katz, A. Stabilizing Single Sites on Solid Supports: Robust Grafted $\mathrm{Ti}(\mathrm{IV})$-Calixarene Olefin Epoxidation Catalysts via Surface Polymerization and Cross-Linking. ACS Catal. 2016, 6, 7760-7768.

(33) Morlanes, N.; Notestein, J. M. Kinetic study of cyclooctene epoxidation with aqueous hydrogen peroxide over silica-supported calixarene-Ta(V). Appl. Catal., A 2010, 387, 45-54.

(34) Akceylan, E.; Uyanika, A.; Eymurb, S.; Sahina, O.; Yilmaz, M. Calixarene-proline functionalized iron oxide magnetite nanoparticles (Calix-Pro-MN): An efficient recyclable organocatalyst for asymmetric aldol reaction in water. Appl. Catal., A 2015, 499, 205-212.

(35) Zhou, Y.; Tan, L.-L.; Li, Q.-L.; Qiu, X.-L.; Qi, A.-D.; Tao, Y.; Yang, Y.-W. Acetylcholine-Triggered Cargo Release from Supramolecular Nanovalves based on Different Macrocyclic Receptors. Chem. - Eur. J. 2014, 20, 2998-3004.

(36) Zhou, Y.; Li, H.; Yang, Y.-W. Controlled drug delivery systems based on calixarenes. Chin. Chem. Lett. 2015, 26, 825-828.

(37) Narkhede, N.; Patel, A.; Singh, S. Mono lacunary phosphomolybdate supported on MCM-41: synthesis, characterization and solvent free aerobic oxidation of alkenes and alcohols. Dalton Trans. 2014, 43, 2512-2520.

(38) Li, W.; Xu, Y.; Zhou, Y.; Ma, W.; Wang, S.; Dai, Y. Silica nanoparticles functionalized via click chemistry and ATRP for enrichment of $\mathrm{Pb}(\mathrm{II})$ ion. Nanoscale Res. Lett. 2012, 7, 485-491.

(39) Parida, K. M.; Rath, D. Amine functionalized MCM-41: An active and reusable catalyst for Knoevenagel condensation reaction. J. Mol. Catal. A: Chem. 2009, 310, 93-100.

(40) Braun, K.; Pochert, A.; Beck, M.; Fiedler, R.; Gruber, J.; Linden, M. Dissolution kinetics of mesoporous silica nanoparticles in different simulated body fluids. J. Sol-Gel Sci. Technol. 2016, 79, 319-327.

(41) Rim, H. P.; Min, K. H.; Lee, H. J.; Jeong, S. Y.; Lee, S. C. pHTunable calcium phosphate covered mesoporous silica nanocontainers for intracellular controlled release of guest drugs. Angew. Chem., Int. Ed. 2011, 50, 8853-8857.

(42) Gutsche, C. D.; Levine, J. A.; Sujeeth, P. K. Functionalized Calixarenes: The Claisen Rearrangement Route. J. Org. Chem. 1985, 50, 5802-5806.

(43) Gutsche, C. D.; Dhawan, B.; Levine, J. A.; No, K. H.; Bauer, L. J. Conformational Isomers of Ethers and Esters of Calix[4]arenes. Tetrahedron 1983, 39, 409-426. 